\title{
HUMAN ENTEROVIRUSES EXHIBIT SELECTIVE ONCOLYTIC ACTIVITY IN THE MODEL OF HUMAN GLIOBLASTOMA MULTIFORME XENOGRAFTS IN IMMUNODEFICIENT MICE
}

Zheltukhin $A O^{1}$, Soboleva $A V^{1,2}$, Sosnovtseva $A O^{1,3}$, Le $\mathrm{TH}^{1}$, llyinskaya $\mathrm{GV}^{1,4}$, Kochetkov $\mathrm{DV}^{1}$, Lipatova $\mathrm{AV}^{1}, \mathrm{Chumakov}^{\mathrm{P}} \mathrm{M}^{1,2} \otimes$

Engelhardt Institute of Molecular Biology, Russian Academy of Sciences, Moscow

Chumakov Federal Scientific Center for Research and Development of Immune-and-Biological Products, Moscow

Pirogov Russian National Research Medical University, Moscow

Blokhin National Medical Research Center of Oncology, Moscow

\begin{abstract}
Stem cells that penetrated deeply into the brain tissue are the main reason behind the relapses of glioblastoma multiforme after surgery. Finding new approaches to counter such relapses, including those that make use of oncolytic viruses, is a pressing issue. This study aimed to determine the sensitivity of cells of human glioblastoma multiforme to non-pathogenic enteroviruses, in vitro and in vivo (mice xenografts model). Glioblastoma tumor cells were exposed to type 1 poliovirus (Sabin vaccine strain), Coxsackie virus A7 (strain LEV8), Coxsackie virus A9 (strain LEV9) and Coxsackie virus B5 (strain LEV14). The virus reproduction intensity and cytolytic activity were assessed through infection of monolayered glioblastoma cell cultures. The ability of glialoblastoma cell cultures (enriched with tumor stem cells) to build subcutaneous tumors in immunodeficient mice after those cultures were exposed to viruses signaled the effectiveness of glioblastoma stem cells destruction. The study revealed that Coxsackie virus A7 and type 1 poliovirus possess the most pronounced oncolytic and replicative properties when tested on gliblastoma cells infected with viruses in vitro and on subcutaneous tumor xenografts in immunodeficient mice (in vivo). Type 1 poliovirus and Coxsackie virus A7 virus prevented development of tumors when glioblastoma neurospheric cell cultures were preincubated with viruses before subcutaneous implantation. Coxsackie virus B5 only managed to reduce the number of tumors developed, and Coxsackie virus A9 did not affect the tumor development at all. Thus, a number of non-pathogenic enteroviruses strains can destroy glioblastoma's stem cells, i.e. they show promise in the context of development of therapeutic agents for relapse-free treatment of glioblastomas.
\end{abstract}

Keywords: glioblastoma multiforme, oncolytic virus, non-pathogenic enteroviruses, personalized medicine, tumor relapse, experimental cancer therapy

Funding: the study was supported by the Ministry of Education and Science of the Russian Federation; project code RFMEFI60714X0014.

$\triangle$ Correspondence should be addressed: Peter M Chumakov

Vavilova, 32, Moscow, 119991; chumakovpm@yahoo.com

Received: 26.06.2018 Accepted: 30.06.18

DOI: $10.24075 / \mathrm{brsmu} .2018 .026$

\section{ЭНТЕРОВИРУСЫ ЧЕЛОВЕКА ПРОЯВЛЯЮТ ИЗБИРАТЕЛЬНУЮ ОНКОЛИТИЧЕСКУЮ АКТИВНОСТЬ НА МОДЕЛИ КСЕНОТРАНСПЛАНТАТОВ МУЛЬТИФОРМНОЙ ГЛИОБЛАСТОМЫ ЧЕЛОВЕКА В ИММУНОДЕФИЦИТНЫХ МЫШАХ}

\author{
А. О. Желтухин ${ }^{1}$, А. В. Соболева ${ }^{1,2}$, А. О. Сосновцева ${ }^{1,3}$, Т. Х. Ле
}

${ }^{1}$ Институт молекулярной биологии имени В. А. Энгельгардта, Москва

2 Федеральный научный центр исследований и разработки иммунобиологических препаратов имени М. П. Чумакова, Москва

${ }^{3}$ Российский национальный исследовательский медицинский университет имени Н. И. Пирогова, Москва

${ }^{4}$ Российский онкологический центр имени Н. Н. Блохина, Москва

Основным источником возникновения рецидивов мультиформной глиобластомы после хирургического вмешательства являются стволовые клетки, успевающие проникнуть глубоко в ткани мозга. В настоящее время актуален поиск новых подходов для борьбы с ними, в том числе с помощью онколитических вирусов. Целью работы было определение чувствительности к непатогенным энтеровирусам клеток мультифформной глиобластомы человека, поддерживаемых in vitro и в модели мышиных ксенотрансплантатов. Культуры опухолевых клеток глиобластом испытывали на чувствительность К полиовирусу 1 типа (штамм вакцины Сэбина), вирусу Коксаки А7 (штамм ЖЭВ8), Коксаки А9 (штамм ЖЭВ9) и Коксаки В5 (Штамм ЖЭВ12). Количественную оценку репродукции вирусов и их цитолитическую активность проводили заражением монослойных культур клеток глиобластомы. Эффективность уничтожения стволовых клеток глиобластомы определяли по способности клеточных культур глиобластом, обогащенных опухолевыми стволовыми клетками, формировать подкожные опухоли у иммунодефицитных мышей после обработки вирусами. По результатам исследования наиболее выраженная онколитическая и репликационная активность выявлена у вируса Коксаки А7 и полиовируса 1 типа при тестировании в модели культур клеток глиобластом, инфицированных вирусами in vitro, а также in vivo, в модели подкожных опухолевых ксенотрансплантатов на иммунодесицитных мышах. Полиовирус 1 типа и вирус Коксакси A7 предотвращали образование опухолей после того как нейроссерные культуры клеток глиобластом преинкубировали с вирусами перед подкожным введением. Вирус Коксаки В5 вызывал лишь частичное сокращение числа опухолей, а Коксаки А9 не влиял на опухолеобразование. Таким образом, ряд штаммов непатогенных энтеровирусов способен уничтожать стволовые клетки глиобластом и представляется перспективным при разработке терапевтических средств для безрецидивного лечения глиобластом.

Ключевые слова: мультиформная глиобластома, онколитический вирус, непатогенные энтеровирусы, персонифицированная медицина, рецидив опухоли, экспериментальная терапия рака

Финансирование: работа выполнена при финансовой поддержке Министерства образования и науки РФ, уникальный код проекта RFMEFI60714Х0014.

$\bowtie$ Для корреспонденции: Петр Михайлович Чумаков

ул. Вавилова, д. 32, г. Москва, 119991; chumakovpm@yahoo.com

Статья получена: 26.06.2018 Статья принята к печати: 30.06.18

DOI: $10.24075 /$ vrgmu.2018.026 
Brain tumors remain hard to treat, especially when they take form of a glioblastoma multiforme, which is the most malignant and practically incurable [1]. Such tumors grow and infiltrate functionally important areas of the brain, making surgery extremely difficult. Often, the risk of neurological disorders dictates minimal invasion, i.e. only partial removal of the tumor However, even when it is removed completely, a relapse is imminent: glioblastoma stem cells that ignite the development of such tumors migrate deeply into the healthy areas of the brain and cannot be removed [2-4]. Chemotherapy and radiotherapy result in short-term remissions only; when they are over, the tumor resumes its growth [4]. Modern medicine is almost out of options when dealing with glioblastomas, which justifies the search for alternative approaches to targeted and effective destruction of malignant cells. Significant progress in understanding the mechanisms of malignant growth and specific properties of glioblastoma cells is a good basis for development of innovative therapies. The particularly promising one implies using non-pathogenic oncolytic viruses that recognize and destroy glioblastoma cells [5, 6].

Members of various virus families are used to design oncolytic viruses to treat human gliomas. Among these are herpes viruses, Newcastle Disease virus [7-11], adenoviruses [12-16], parvoviruses [17-19], reoviruses [20-23] , enteroviruses [24-27] etc [1]. Numerous clinical trials have shown that oncolytic virus preparations are non-toxic [28-31]. In addition, unlike chemo- and targeted therapy, many oncolytic viruses can effectively kill tumor-initiating stem cells [16, 32-37], which is crucial for the complete recovery of patients. Today, there is a wide range of potentially therapeutic virus strains that can be used in further clinical trials. Properties of non-pathogenic strains of Coxsackie viruses (A7, A9 and B5 in particular) are being studied actively, and preliminary data suggest that they can potentially form therapeutic agents [38].

This study aimed at evaluating the response of glioblastoma tumor cells to oncolytic action of a number of non-pathogenic enteroviruses in in vitro and in vivo models in order to uncover and assess their therapeutic potentials for a treatment of glioblastomas.

\section{MATERIALS AND METHODS}

\section{Obtaining primary cell cultures from glioblastoma tumors}

Fragments of the freshly removed tumors were stored for up to 12 hours in ice-cold sterile culture medium. Pieces of tumors were mechanically separated from necrotic tissue, stroma, blood vessels, and then gently pushed through a nylon mesh (pore size $-50 \mu \mathrm{m}$ ). The tumor cell aggregate suspension was washed with PBS and incubated in 25 volumes of collagenase 4 solution (PanEco, Moscow) for 25 minutes at $30^{\circ} \mathrm{C}$. To obtain monolayer glioblastoma cells cultures, the suspension treated with collagenase was washed twice with DMEM (PanEco, Moscow) and placed in DMEM-F12 supplemented with $10 \%$ fetal bovine serum and $100 \mu \mathrm{g} / \mathrm{ml}$ of penicillin and streptomycin at the density of $10^{5} \mathrm{cells} / \mathrm{ml}$. The incubation was at $37^{\circ} \mathrm{C}$ in the atmosphere of $5 \% \mathrm{CO}_{2}$; the medium was replaced every 4 days up until the monolayers formed. 18-25 days after the incubation, monolayer cultures were placed to $10 \mathrm{~cm}$ culture dishes.

\section{Growth of tumor xenografts in immunodeficient mice}

We obtained the xenografts of subcutaneous tumors by injecting neurospheres, which were obtained by the alternative method of plating cells from glioblastomas after treating tumor fragments with collagenase 4 (PanEco, Moscow). The plating conditions were as follows: density $-10^{4}$ cells $/ \mathrm{ml}$; medium - DMEM-F12; supplements - $100 \mu \mathrm{g} / \mathrm{ml}$ penicillin and streptomycin; growth factor - $20 \mathrm{ng} / \mathrm{ml} \mathrm{EGF}$ and $10 \mathrm{ng} / \mathrm{ml}$ bFGF. The cultures stayed in a $\mathrm{CO}_{2}$ incubator at $37^{\circ} \mathrm{C}$ for 2 weeks; the medium was replaced every 4 days until visible neurospheres appeared. The neurospheres enriched with glioblastoma stem cells are highly tumorigenic when injected to immunodeficient mice. For implantation purposes, the neurospheres were washed twice with PBS, their numbers counted with a hemocytometer. 3-5-week-old athymic Balb/c mice received 200 neurospheres subcutaneously, injection location - shoulder. The tumor growth was monitored every 3 days; the total number of tumors was assessed on the day 21 .

\section{Strains of oncolytic viruses}

We used non-pathogenic strains of human enteroviruses from the laboratory's collection: type 1 poliovirus (Sabin vaccine strain), Coxsackie virus A7 (strain LEV8), Coxsackie virus A9 (strain LEV9) and Coxsackie virus B5 (strain LEV14) [38, 39]. Enteroviruses were grown in Vero cells. Viral titres as TCID50/ $\mathrm{ml}$ were determined by infecting Vero cells with serial dilutions of the virus-containing liquid.

\section{Testing sensitivity of glioblastomas cells to viruses}

We used the tumor material from two patients with glioblastomas to determine the differential sensitivity of cells (after a minimal number of passages in the culture) to the panel of oncolytic enteroviruses. The cultures obtained from these patients were named GM-3564 and GM-3876. 96-well culture plates (SPL Lifesciences, Republic of Korea) were used to infect the cultures. Subconfluent one-day monolayers of GM-3564 and GM-3876 cell cultures, as well as Vero control cells, were incubated with $0.1 \mathrm{ml}$ serial virus dilutions. We measured cell viability seven hours after infecting the cultures with serial tenfold dilutions of viral preparations (four non-pathogenic enteroviruses). After 72 hours, we evaluated the cytopathic activity using the CellTiterGlo ${ }^{\circledast}$ Luminescent Cell Viability Assay kit (Promega, USA).

\section{In vivo virus introduction}

To measure the ability of viruses to prevent formation of tumors with neurospheres injected, we incubated neurospheres with viruses prior to subcutaneous administration $\left(2 \times 10^{6}\right.$ virus infectious units (i.u.), volume $0.1 \mathrm{ml}$, for 30 minutes at $37^{\circ} \mathrm{C}$ ).

\section{RESULTS}

We tested sensitivity of the monolayer glioblastoma cultures (obtained from tumors in two patients) to four strains of enteroviruses. GM-3564 cells were most susceptible to Coxsackie virus A7 and slightly less so to type I poliovirus (Fig. 1). GM-3876 culture showed quite the opposite: type I poliovirus was the strongest agent in its case and Coxsackie virus A7 produced a similar effect only when the dose was about ten times larger. Both cultures were relatively resistant to Coxsackie virus $\mathrm{B} 5$ and almost completely resistant to Coxsackie virus A9. The latter produced a slight toxic effect only at maximum doses. At the same time, all for strains were cytotoxic to the Vero cells (control) at approximately the same dosage. Thus, the two cultures of glioblastomas are apparently selective in their sensitivity to virus strains, and the lysing activity of those 
strains depends on that sensitivity. The probable explanation is the differing ability to support replication of viruses the cultures exhibit.

In order to establish the ability of viral strains to prevent formation of subcutaneous tumors following introduction of xenografts into immunodeficient mice, we obtained cultures of neurospheres from tumor material of glioblastoma patients. The neurospheres received tumor-forming stem cells, which made their tumorigenicity significantly greater than that of monolayer glioblastoma cell cultures. Obtaining neurosphere cultures requires medium with specific growth factors, EGF and bFGF. In addition, the cells should be plated to a non-adhering plastic surface preventing attachment of cells. In such conditions, glioblastoma cells form spheroid aggregates, or neurospheres, which are enriched in tumor-forming stem cells. Since counting the number of individual cells in spheroids is difficult, in order to standardize the procedure of subcutaneous injections aiming tumor development we counted the number of neurospheres. In our preliminary study, we found that injecting 200 neurospheres leads to the formation of tumors within 1-2.5 weeks. The control group of five mice received 200 neurospheres in a volume of $0.5 \mathrm{ml}$ subcutaneously in the shoulder region. We used the same number of mice to test the effect produced by viruses on tumor formation. Thus, each group of mice could develop up to 10 tumors. To test the ability of viruses to prevent formation of tumors from the injected neurospheres, the latter were incubated with viruses (see Materials and Methods). We used five mice for each type of virus; they were injected with a suspension containing virus-treated neurospheres (two injection points). The resulting tumors were counted 21 days after the injection. Assessing the tumors, we did not take into account their size (Fig. 2). 9 tumors (out of 10) developed in the control group injected with GM-5564 neurospheres. Treatment with type 1 poliovirus completely suppressed the formation of the tumors; Coxsackie virus A7 showed a less prominent result: one tumor did develop, but at a later date. Treatment with the Coxsackie virus B5 lead to the formation of three tumors, while Coxsackie virus A9 showed almost no anti-tumor effect (8 tumors). Groups of mice that received the GM-3876 neurospheres showed principally similar results: 8 tumors in the control group (out of 10 possible), no tumors after treatment with poliovirus and Coxsackie virus A7, 4 tumors in the group treated with the Coxsackie virus B5, 8 tumors in the Coxsackie virus $A 9$ group.

\section{DISCUSSION}

Neurosphere cultures are the most adequate model for analyzing the therapeutic potential of anti-glioblastoma agents [40]. This is due to the fact that neurospheres carry tumor stem cells, which are the main cause of relapses: they are very resistant to most therapeutic agents [41]. In this study,

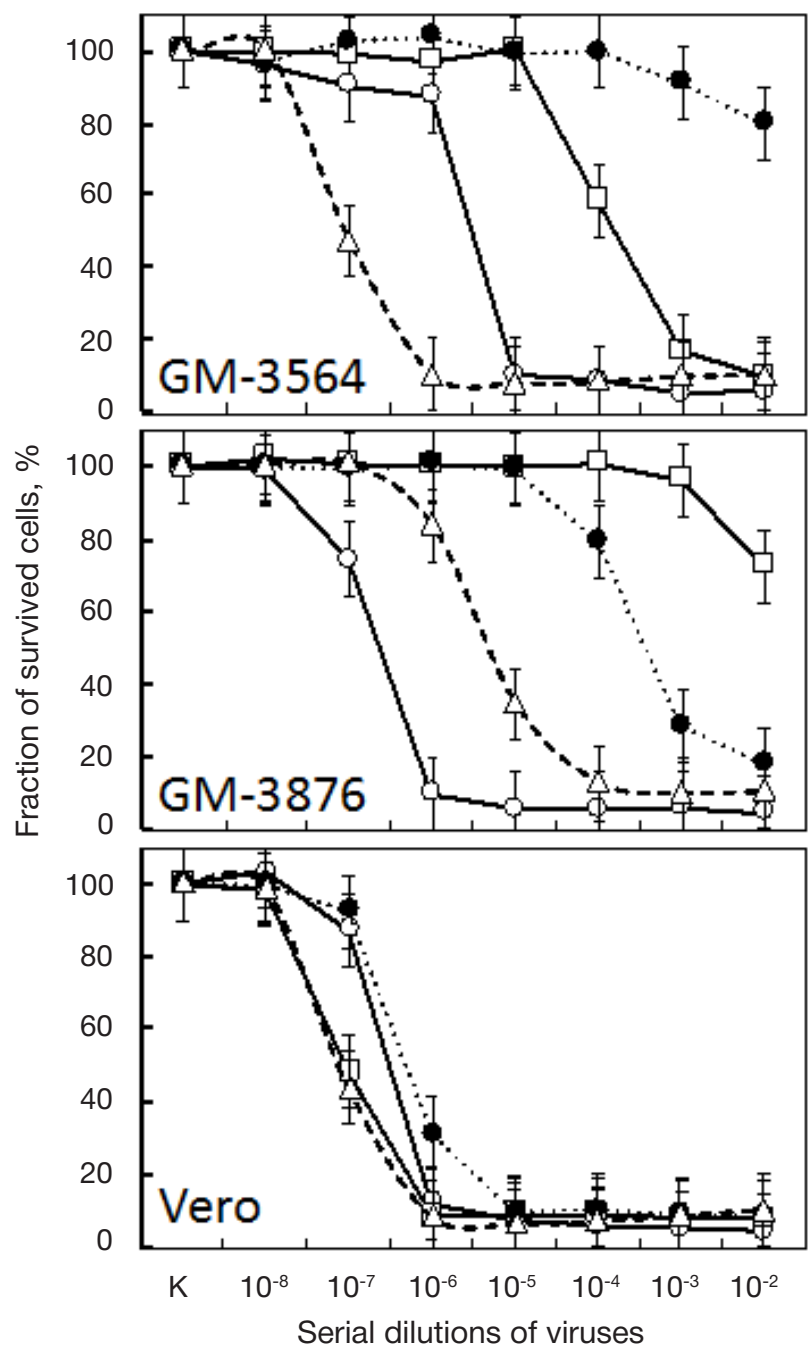

Fig. 1. Sensitivity of early-passage monolayer cell cultures obtained from two glioblastoma patients to four strains oncolytic enteroviruses: - O - Type 1 Poliovirus; - - $\triangle$ - - Coxsackie virus A7; $\square \square-$ Coxsackie virus A9; .... . ... Coxsackie virus B5. Horizontal scale: $10^{-8}-10^{-2}-$ ten-fold serial dilutions of viral stocks used for the infections. Vero - control cell line that is sensitive to all four types of viruses used 


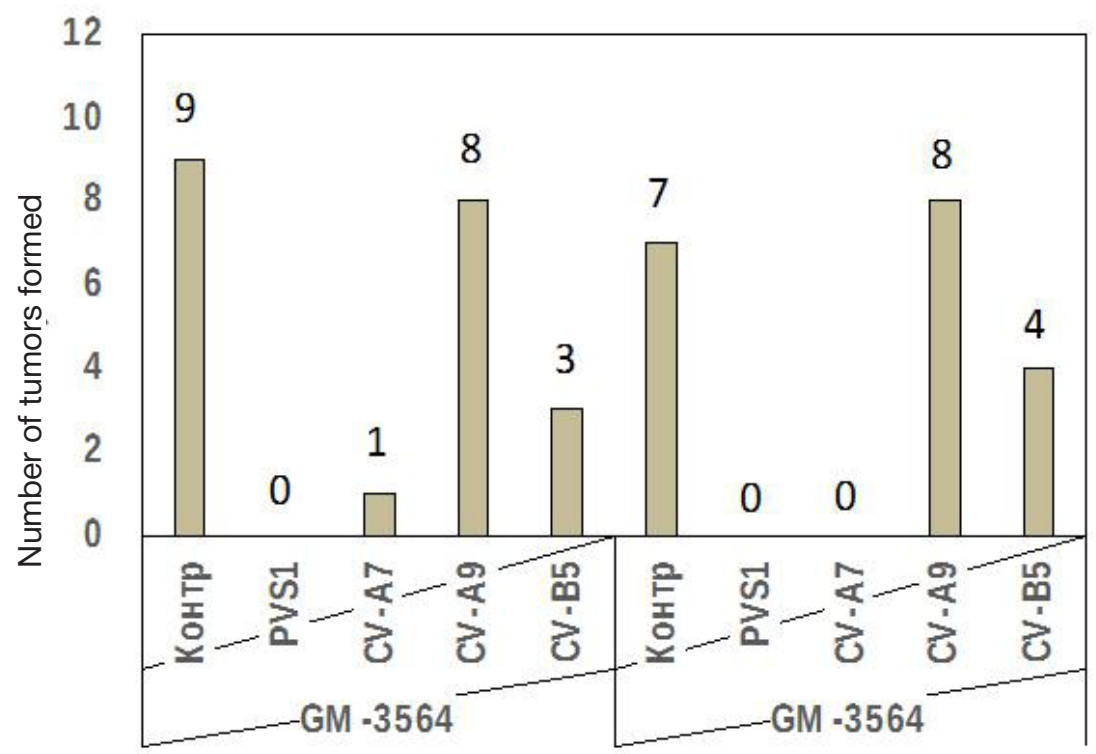

Fig. 2. Tumorigenicity-inhibition assay with glioblastoma neurosheres pretreated with each $\mathrm{f}$ the four viruses before being injected subcutaneously into nude mice. Bars reflect number of tumors formed in each treated and untereated (Contr) group of mice. PVS1 — Type 1 Poliovirus; CV-A7 — Coxsackie virus A7; CV-A9 — Coxsackie virus A9; CV-B5 - Coxsackie virus B5

we analyzed the ability of four non-pathogenic oncolytic enteroviruses to prevent the formation of subcutaneous tumor xenografts obtained through injecting neurospheres that were developed from the tumor material of two glioblastoma patients. The results of the study indicate that two viral strains, type 1 poliovirus and Coxsackie virus A7 were the most effective. However, neurospheres from the two different patients reacted to those viruses differently, which points to the need for a personalized selection of the most effective therapeutic strains after preliminary analysis of biopsy or surgical material taken from the patients' tumors. The recently published results of clinical trials of recombinant poliovirus PVSRIPO prove its ability to initiate prolonged remissions in $21 \%$ of glioblastoma patients, while the remaining patients saw no therapeutic effect from the virus [42]. Adding more therapeutic virus strains to the range available will significantly increase the percentage of successfully treated glioblastoma cases.

\section{References}

1. Gubanova NV, Gaytan AS, Razumov IA, Mordvinov VA, Krivoshapkin AL, Netesov SV, i dr. Onkoliticheskie virusy v terapil gliom. Molekuljarnaja biologija. 2012; 46 (6): 726-38.

2. Greenberg MS. Handbook of Neurosurgery. 7th ed. New York: Thieme Publishers; 2010.

3. Park DM, Rich JN. Biology of glioma cancer stem cells. Molecules and cells. 2009; 28 (1): 7-12. DOI: 10.1007/s10059-009-0111-2. PubMed PMID: 19655094.

4. Claes A, Idema AJ, Wesseling P. Diffuse glioma growth: a guerilla war. Acta Neuropathol. 2007; 114 (5): 443-58. DOl: 10.1007/ s00401-007-0293-7. PubMed PMID: 17805551; PubMed Central PMCID: PMCPMC2039798.

5. Buonaguro FM, Tornesello ML, Izzo F, Buonaguro L. Oncolytic virus therapies. Pharmaceutical patent analyst. 2012; 1 (5): 62127. DOI: 10.4155/ppa.12.65. PubMed PMID: 24236929.

6. Parker JN, Bauer DF, Cody JJ, Markert JM. Oncolytic viral therapy of malignant glioma. Neurotherapeutics. 2009; 6 (3): 558-69.

7. Zulkifli MM, Ibrahim R, Ali AM, Aini I, Jaafar H, Hilda SS, et al. Newcastle diseases virus strain V4UPM displayed oncolytic ability against experimental human malignant glioma. Neurological research. 2009; 31 (1): 3-10. DOI: 10.1179/174313208×325218.

\section{CONCLUSIONS}

Based on the results of the study, we conclude that each of the four strains of non-pathogenic oncolytic enteroviruses produces cytolitic effect on monolayer cell cultures of human glioblastomas, and that the effect correlates well with the ability of the same strains to prevent tumor formation in xenografts transplanted to immunodeficient mice. Thus, there is a clear relationship between the effects produced by the viruses in vitro and their oncolytic activity in vivo. Besides, it was found that viruses that can efficiently replicate in monolayer glioblastoma cell cultures can effectively kill tumor-initiating glioblastoma stem cells, which signals the high oncolytic potential of the viruses in preventing tumor relapses. The differences in reaction to viruses that tumor cells from two patients have shown indicate the need for personalized selection of therapeutic strains.
PubMed PMID: 18937888.

8. Wagner S, Csatary CM, Gosztonyi G, Koch HC, Hartmann C, Peters $\mathrm{O}$, et al. Combined treatment of pediatric high-grade glioma with the oncolytic viral strain $\mathrm{MTH}-68 / \mathrm{H}$ and oral valproic acid. Apmis. 2006; 114 (10): 731-43.

9. Freeman Al, Zakay-Rones Z, Gomori JM, Linetsky E, Rasooly L, Greenbaum E, et al. Phase 1//l trial of intravenous NDV-HUJ oncolytic virus in recurrent glioblastoma multiforme. Mol Ther. 2006; 13 (1): 221-28.

10. Csatary LK, Gosztonyi G, Szeberenyi J, Fabian Z, Liszka V, Bodey B, et al. MTH-68/H oncolytic viral treatment in human highgrade gliomas. J Neurooncol. 2004; 67 (1-2): 83-93.

11. Csatary LK, Bakacs T. Use of Newcastle disease virus vaccine (MTH-68/H) in a patient with high-grade glioblastoma. JAMA. 1999; 281 (17): 588-89.

12. Tsamis KI, Alexiou GA, Vartholomatos E, Kyritsis AP. Combination treatment for glioblastoma cells with tumor necrosis factor-related apoptosis-inducing ligand and oncolytic adenovirus delta-24. Cancer Invest. 2013; 31 (9): 630-38. DOI: 10.3109/07357907.2013.849724. PubMed PMID: 24164301.

13. Li X, Mao Q, Wang D, Xia H. A novel Ad5/11 chimeric oncolytic 
adenovirus for improved glioma therapy. Int J Oncol. 2012; 41 (6): 2159-65. DOI: 10.3892/ijo.2012.1674. PubMed PMID: 23117867

14. Alonso MM, Jiang H, Gomez-Manzano C, Fueyo J. Targeting brain tumor stem cells with oncolytic adenoviruses. Methods Mol Biol. 2012; 797: 111-25.

15. Ahmed AU, Ulasov IV, Mercer RW, Lesniak MS. Maintaining and loading neural stem cells for delivery of oncolytic adenovirus to brain tumors. Methods Mol Biol. 2012; 797: 97-109.

16. Gomez-Manzano C, Fueyo J. Oncolytic adenoviruses for the treatment of brain tumors. Curr Opin Mol Ther. 2010; 12 (5): 53037.

17. Lacroix J, Schlund F, Leuchs B, Adolph K, Sturm D, Bender S, et al. Oncolytic effects of parvovirus $\mathrm{H}-1$ in medulloblastoma are associated with repression of master regulators of early neurogenesis. Int J Cancer. 2014; 134 (3): 703-16. DOI: 10.1002/ ijc.28386. PubMed PMID: 23852775.

18. Paglino JC, Ozduman K, van den Pol AN. Lulll parvovirus selectively and efficiently targets, replicates in, and kills human glioma cells. J Virol. 2012; 86 (13): 7280-91.

19. Geletneky K, Huesing J, Rommelaere J, Schlehofer JR, Leuchs B, Dahm M, et al. Phase 1/lla study of intratumoral/intracerebral or intravenous/intracerebral administration of Parvovirus $\mathrm{H}-1$ (ParvOryx) in patients with progressive primary or recurrent glioblastoma multiforme: ParvOryx01 protocol. BMC cancer. 2012; 12: 99

20. Kicielinski KP, Chiocca EA, Yu JS, Gill GM, Coffey M, Markert JM. Phase 1 clinical trial of intratumoral reovirus infusion for the treatment of recurrent malignant gliomas in adults. Mol Ther. 2014; 22 (5): 1056-62. DOl: 10.1038/mt.2014.21. PubMed PMID: 24553100; PubMed Central PMCID: PMCPMC4015229.

21. van den Wollenberg DJ, Dautzenberg IJ, van den Hengel SK, Cramer SJ, de Groot RJ, Hoeben RC. Isolation of reovirus T3D mutants capable of infecting human tumor cells independent of junction adhesion molecule-A. PLoS One. 2012; 7 (10): e48064. DOI: 10.1371/journal.pone.0048064. PubMed PMID: 23110175; PubMed Central PMCID: PMCPMC3480499.

22. Forsyth P, Roldan G, George D, Wallace C, Palmer CA, Morris D, et al. A phase I trial of intratumoral administration of reovirus in patients with histologically confirmed recurrent malignant gliomas. Mol Ther. 2008; 16 (3): 627-32.

23. Wilcox ME, Yang W, Senger D, Rewcastle NB, Morris DG, Brasher PM, et al. Reovirus as an oncolytic agent against experimental human malignant gliomas. J Natl Cancer Inst. 2001; 93 (12): 903-12. PubMed PMID: 11416111

24. Goetz C, Dobrikova E, Shveygert M, Dobrikov M, Gromeier M. Oncolytic poliovirus against malignant glioma. Future Virol. 2011; 6 (9): 1045-58.

25. Goetz C, Gromeier M. Preparing an oncolytic poliovirus recombinant for clinical application against glioblastoma multiforme. Cytokine Growth Factor Rev. 2010; 21 (2-3): 197-203. DOI: 10.1016/j.cytogfr.2010.02.005. PubMed PMID: 20299272; PubMed Central PMCID: PMCPMC2881183.

26. Dobrikova EY, Broadt T, Poiley-Nelson J, Yang X, Soman G, Giardina $S$, et al. Recombinant oncolytic poliovirus eliminates glioma in vivo without genetic adaptation to a pathogenic phenotype. Mol Ther. 2008; 16 (11): 1865-72.

27. Gromeier M, Lachmann S, Rosenfeld MR, Gutin PH, Wimmer E. Intergeneric poliovirus recombinants for the treatment of malignant glioma. Proc Natl Acad Sci USA. 2000; 97 (12): 6803-08.

28. Lawler SE, Speranza MC, Cho CF, Chiocca EA. Oncolytic Viruses in Cancer Treatment: A Review. JAMA oncology. 2017; 3 (6): 841-49. DOI: 10.1001/jamaoncol.2016.2064. PubMed PMID: 27441411.

29. Pol J, Buque A, Aranda F, Bloy N, Cremer I, Eggermont A, et al. Trial Watch-Oncolytic viruses and cancer therapy. Oncoimmunology. 2016; 5 (2): e1117740. DOI: 10.1080/2162402x.2015.1117740. PubMed PMID: 27057469; PubMed Central PMCID: PMCPMC4801444.

30. Taguchi S, Fukuhara H, Homma Y, Todo T. Current status of clinical trials assessing oncolytic virus therapy for urological cancers. Int J Urol. 2017; 24 (5): 342-51. DOI: 10.1111/iju.13325. PubMed PMID: 28326624

31. Warner SG, O'Leary MP, Fong Y. Therapeutic oncolytic viruses: clinical advances and future directions. Curr Opin Oncol. 2017; 29 (5): 359-65. DOI: 10.1097/cco.0000000000000388. PubMed PMID: 28678032

32. Bach P, Abel T, Hoffmann C, Gal Z, Braun G, Voelker I, et al. Specific elimination of CD133+ tumor cells with targeted oncolytic measles virus. Cancer Res. 2013; 73 (2): 865-74. DOI: 10.1158/0008-5472.can-12-2221. PubMed PMID: 23293278.

33. Berghauser Pont LM, Balvers RK, Kloezeman JJ, Nowicki MO, van den Bossche W, Kremer A, et al. In vitro screening of clinical drugs identifies sensitizers of oncolytic viral therapy in glioblastoma stem-like cells. Gene Ther. 2015. DOI: 10.1038/ gt.2015.72. PubMed PMID: 26196249.

34. Dey M, Ulasov IV, Lesniak MS. Virotherapy against malignant glioma stem cells. Cancer Lett. 2010; 289 (1): 1-10.

35. Liu J, Ma L, Xu J, Liu C, Zhang J, Liu J, et al. Spheroid bodyforming cells in the human gastric cancer cell line MKN-45 possess cancer stem cell properties. Int J Oncol. 2013; 42 (2): 453-59. DOI: 10.3892/ijo.2012.1720. PubMed PMID: 23229446; PubMed Central PMCID: PMCPMC3583623.

36. Sgubin D, Wakimoto H, Kanai R, Rabkin SD, Martuza RL. Oncolytic herpes simplex virus counteracts the hypoxia-induced modulation of glioblastoma stem-like cells. Stem cells translational medicine. 2012; 1 (4): 322-32. DOI: 10.5966/sctm.2011-0035. PubMed PMID: 23197811; PubMed Central PMCID: PMCPMC3659700.

37. van den Hengel SK, Balvers RK, Dautzenberg IJ, van den Wollenberg DJ, Kloezeman JJ, Lamfers ML, et al. Heterogeneous reovirus susceptibility in human glioblastoma stem-like cell cultures. Cancer Gene Ther. 2013; 20 (9): 507-13. DOI: 10.1038/ cgt.2013.47. PubMed PMID: 23907517.

38. Chumakov PM, Morozova W, Babkin IV, Baykov IK, Netesov SV Tikunova NV. Onkoliticheskie enterovirusy. Molekuljarnaja biologija. 2012; 46 (6): 712-25.

39. Voroshilova MK, Magazanik SS, Chumakov PM. Poleznye virusy cheloveka. Aktual'nye voprosy epidemiologii, mikrobiologii infekzionnyh zabolevaniy. Tashkent: Medicina; 1980. p. 227-29.

40. Wang $X$, Yang $K$, Xie Q, Wu Q, Mack SC, Shi $Y$, et al. Purine synthesis promotes maintenance of brain tumor initiating cells in glioma. Nature neuroscience. 2017; 20 (5): 661-73. DOl: 10.1038/nn.4537. PubMed PMID: 28346452; PubMed Central PMCID: PMCPMC6015494.

41. Lathia JD, Mack SC, Mulkearns-Hubert EE, Valentim CL, Rich JN Cancer stem cells in glioblastoma. Genes Dev. 2015; 29 (12): 1203-17. DOI: 10.1101/gad.261982.115. PubMed PMID: 26109046; PubMed Central PMCID: PMCPMC4495393.

42. Desjardins A, Gromeier M, Herndon JE, 2nd, Beaubier N, Bolognesi DP, Friedman AH, et al. Recurrent Glioblastoma Treated with Recombinant Poliovirus. N Engl J Med. 2018; DOI: 10.1056/ NEJMoa1716435. PubMed PMID: 29943666.

\section{Литература}

1. Губанова Н. В., Гайтан А. С., Разумов И. А., Мордвинов В. А., Кривошапкин А. Л., Нетесов С. В., и др. Онколитические вирусы в терапии глиом. Молекулярная биология. 2012; 46 (6): 726-38

2. Greenberg MS. Handbook of Neurosurgery. 7th ed. New York:
Thieme Publishers: 2010

3. Park DM, Rich JN. Biology of glioma cancer stem cells. Molecules and cells. 2009; 28 (1): 7-12. DOI: 10.1007/s10059-009-0111-2. PubMed PMID: 19655094.

4. Claes A, Idema AJ, Wesseling P. Diffuse glioma growth: a guerilla 
war. Acta Neuropathol. 2007; 114 (5): 443-58. DOl: 10.1007/ s00401-007-0293-7. PubMed PMID: 17805551; PubMed Central PMCID: PMCPMC2039798.

5. Buonaguro FM, Tornesello ML, Izzo F, Buonaguro L. Oncolytic virus therapies. Pharmaceutical patent analyst. 2012; 1 (5): $621-$ 27. DOI: 10.4155/ppa.12.65. PubMed PMID: 24236929.

6. Parker JN, Bauer DF, Cody JJ, Markert JM. Oncolytic viral therapy of malignant glioma. Neurotherapeutics. 2009; 6 (3): 558-69.

7. Zulkifli MM, Ibrahim R, Ali AM, Aini I, Jaafar H, Hilda SS, et al. Newcastle diseases virus strain V4UPM displayed oncolytic ability against experimental human malignant glioma. Neurological research. 2009; 31 (1): 3-10. DOI: 10.1179/174313208×325218. PubMed PMID: 18937888.

8. Wagner S, Csatary CM, Gosztonyi G, Koch HC, Hartmann C Peters $\mathrm{O}$, et al. Combined treatment of pediatric high-grade glioma with the oncolytic viral strain $\mathrm{MTH}-68 / \mathrm{H}$ and oral valproic acid. Apmis. 2006; 114 (10): 731-43.

9. Freeman Al, Zakay-Rones Z, Gomori JM, Linetsky E, Rasooly L, Greenbaum E, et al. Phase I/II trial of intravenous NDV-HUJ oncolytic virus in recurrent glioblastoma multiforme. Mol Ther. 2006; 13 (1): 221-28.

10. Csatary LK, Gosztonyi G, Szeberenyi J, Fabian Z, Liszka V, Bodey $\mathrm{B}$, et al. MTH-68/H oncolytic viral treatment in human highgrade gliomas. J Neurooncol. 2004; 67 (1-2): 83-93.

11. Csatary LK, Bakacs T. Use of Newcastle disease virus vaccine $(\mathrm{MTH}-68 / \mathrm{H})$ in a patient with high-grade glioblastoma. JAMA. 1999; 281 (17): 588-89.

12. Tsamis KI, Alexiou GA, Vartholomatos E, Kyritsis AP. Combination treatment for glioblastoma cells with tumor necrosis factor-related apoptosis-inducing ligand and oncolytic adenovirus delta-24. Cancer Invest. 2013; 31 (9): 630-38. DOI: 10.3109/07357907.2013.849724. PubMed PMID: 24164301.

13. Li X, Mao Q, Wang D, Xia H. A novel Ad5/11 chimeric oncolytic adenovirus for improved glioma therapy. Int J Oncol. 2012; 41 (6): 2159-65. DOI: 10.3892/ijo.2012.1674. PubMed PMID: 23117867

14. Alonso MM, Jiang H, Gomez-Manzano C, Fueyo J. Targeting brain tumor stem cells with oncolytic adenoviruses. Methods Mo Biol. 2012; 797: 111-25.

15. Ahmed AU, Ulasov IV, Mercer RW, Lesniak MS. Maintaining and loading neural stem cells for delivery of oncolytic adenovirus to brain tumors. Methods Mol Biol. 2012; 797: 97-109.

16. Gomez-Manzano C, Fueyo J. Oncolytic adenoviruses for the treatment of brain tumors. Curr Opin Mol Ther. 2010; 12 (5): 53037.

17. Lacroix J, Schlund F, Leuchs B, Adolph K, Sturm D, Bender S, et al. Oncolytic effects of parvovirus $\mathrm{H}-1$ in medulloblastoma are associated with repression of master regulators of early neurogenesis. Int J Cancer. 2014; 134 (3): 703-16. DOI: 10.1002 ijc.28386. PubMed PMID: 23852775.

18. Paglino JC, Ozduman K, van den Pol AN. Lulll parvovirus selectively and efficiently targets, replicates in, and kills human glioma cells. J Virol. 2012; 86 (13): 7280-91.

19. Geletneky K, Huesing J, Rommelaere J, Schlehofer JR, Leuchs B, Dahm M, et al. Phase I/lla study of intratumoral/intracerebra or intravenous/intracerebral administration of Parvovirus $\mathrm{H}-1$ (ParvOryx) in patients with progressive primary or recurrent glioblastoma multiforme: ParvOryx01 protocol. BMC cancer. 2012; 12: 99

20. Kicielinski KP, Chiocca EA, Yu JS, Gill GM, Coffey M, Markert JM. Phase 1 clinical trial of intratumoral reovirus infusion for the treatment of recurrent malignant gliomas in adults. Mol Ther 2014; 22 (5): 1056-62. DOl: 10.1038/mt.2014.21. PubMed PMID: 24553100; PubMed Central PMCID: PMCPMC4015229.

21. van den Wollenberg DJ, Dautzenberg IJ, van den Hengel SK Cramer SJ, de Groot RJ, Hoeben RC. Isolation of reovirus T3D mutants capable of infecting human tumor cells independent of junction adhesion molecule-A. PLoS One. 2012; 7 (10): e48064. DOI: 10.1371/journal.pone.0048064. PubMed PMID: 23110175; PubMed Central PMCID: PMCPMC3480499.

22. Forsyth P, Roldan G, George D, Wallace C, Palmer CA, Morris D, et al. A phase I trial of intratumoral administration of reovirus in patients with histologically confirmed recurrent malignant gliomas.
Mol Ther. 2008; 16 (3): 627-32.

23. Wilcox ME, Yang W, Senger D, Rewcastle NB, Morris DG, Brasher PM, et al. Reovirus as an oncolytic agent against experimental human malignant gliomas. J Natl Cancer Inst. 2001; 93 (12): 903-12. PubMed PMID: 11416111

24. Goetz C, Dobrikova E, Shveygert M, Dobrikov M, Gromeier M Oncolytic poliovirus against malignant glioma. Future Virol. 2011; 6 (9): 1045-58

25. Goetz C, Gromeier M. Preparing an oncolytic poliovirus recombinant for clinical application against glioblastoma multiforme. Cytokine Growth Factor Rev. 2010; 21 (2-3): 197-203. DOI: 10.1016/j.cytogfr.2010.02.005. PubMed PMID: 20299272; PubMed Central PMCID: PMCPMC2881183.

26. Dobrikova EY, Broadt T, Poiley-Nelson J, Yang X, Soman G, Giardina $S$, et al. Recombinant oncolytic poliovirus eliminates glioma in vivo without genetic adaptation to a pathogenic phenotype. Mol Ther. 2008; 16 (11): 1865-72.

27. Gromeier M, Lachmann S, Rosenfeld MR, Gutin PH, Wimmer E. Intergeneric poliovirus recombinants for the treatment of malignant glioma. Proc Natl Acad Sci USA. 2000; 97 (12): 6803-08.

28. Lawler SE, Speranza MC, Cho CF, Chiocca EA. Oncolytic Viruses in Cancer Treatment: A Review. JAMA oncology. 2017; 3 (6): 841-49. DOI: 10.1001/jamaoncol.2016.2064. PubMed PMID: 27441411.

29. Pol J, Buque A, Aranda F, Bloy N, Cremer I, Eggermont A, et al. Trial Watch-Oncolytic viruses and cancer therapy. Oncoimmunology. 2016; 5 (2): e1117740. DOI: 10.1080/2162402x.2015.1117740. PubMed PMID: 27057469; PubMed Central PMCID: PMCPMC4801444.

30. Taguchi S, Fukuhara H, Homma Y, Todo T. Current status of clinical trials assessing oncolytic virus therapy for urological cancers. Int J Urol. 2017; 24 (5): 342-51. DOI: 10.1111/iju.13325. PubMed PMID: 28326624

31. Warner SG, O'Leary MP, Fong Y. Therapeutic oncolytic viruses: clinical advances and future directions. Curr Opin Oncol. 2017; 29 (5): 359-65. DOI: 10.1097/cco.0000000000000388. PubMed PMID: 28678032

32. Bach P, Abel T, Hoffmann C, Gal Z, Braun G, Voelker I, et al Specific elimination of CD133+ tumor cells with targeted oncolytic measles virus. Cancer Res. 2013; 73 (2): 865-74. DOl: 10.1158/0008-5472.can-12-2221. PubMed PMID: 23293278.

33. Berghauser Pont LM, Balvers RK, Kloezeman JJ, Nowicki MO, van den Bossche W, Kremer A, et al. In vitro screening of clinical drugs identifies sensitizers of oncolytic viral therapy in glioblastoma stem-like cells. Gene Ther. 2015. DOI: 10.1038/ gt.2015.72. PubMed PMID: 26196249.

34. Dey M, Ulasov IV, Lesniak MS. Virotherapy against malignant glioma stem cells. Cancer Lett. 2010; 289 (1): 1-10.

35. Liu J, Ma L, Xu J, Liu C, Zhang J, Liu J, et al. Spheroid bodyforming cells in the human gastric cancer cell line MKN-45 possess cancer stem cell properties. Int J Oncol. 2013; 42 (2): 453-59. DOI: 10.3892/ijo.2012.1720. PubMed PMID: 23229446; PubMed Central PMCID: PMCPMC3583623.

36. Sgubin D, Wakimoto H, Kanai R, Rabkin SD, Martuza RL. Oncolytic herpes simplex virus counteracts the hypoxia-induced modulation of glioblastoma stem-like cells. Stem cells translational medicine. 2012; 1 (4): 322-32. DOI: 10.5966/sctm.2011-0035. PubMed PMID: 23197811; PubMed Central PMCID: PMCPMC3659700.

37. van den Hengel SK, Balvers RK, Dautzenberg IJ, van den Wollenberg DJ, Kloezeman JJ, Lamfers ML, et al. Heterogeneous reovirus susceptibility in human glioblastoma stem-like cell cultures. Cancer Gene Ther. 2013; 20 (9): 507-13. DOI: 10.1038/ cgt.2013.47. PubMed PMID: 23907517.

38. Чумаков П. М., Морозова В. В., Бабкин И. В., Байков И. К., Нетесов С. В., Тикунова Н. В. Онколитические энтеровирусы. Молекулярная биология. 2012; 46 (6): 712-25.

39. Ворошилова М. К., Магазаник С. С., Чумаков П. М. Полезные вирусы человека. Актуальные вопросы эпидемиологии микробиологии и инфекционных заболеваний. Ташкент: Медицина; 1980. р. 227-29.

40. Wang X, Yang K, Xie Q, Wu Q, Mack SC, Shi Y, et al. Purine synthesis promotes maintenance of brain tumor initiating cells in glioma. Nature neuroscience. 2017; 20 (5): 661-73. DOI: 


\section{ORIGINAL RESEARCH I VIROLOGY}

10.1038/nn.4537. PubMed PMID: 28346452; PubMed Central PMCID: PMCPMC6015494.

41. Lathia JD, Mack SC, Mulkearns-Hubert EE, Valentim CL, Rich JN. Cancer stem cells in glioblastoma. Genes Dev. 2015; 29 (12): 1203-17. DOI: 10.1101/gad.261982.115. PubMed PMID: 26109046; PubMed Central PMCID: PMCPMC4495393.
42. Desjardins A, Gromeier M, Herndon JE, 2nd, Beaubier N, Bolognesi DP, Friedman $\mathrm{AH}$, et al. Recurrent Glioblastoma Treated with Recombinant Poliovirus. N Engl J Med. 2018; DOI: 10.1056/NEJMoa1716435. PubMed PMID: 29943666. 